\title{
Journal of Ecology
}

DR ANABELLE WILLIAMSON CARDOSO (Orcid ID : 0000-0002-4327-7259)

DR IMMA OLIVERAS (Orcid ID : 0000-0001-5345-2236)

Article type : Research Article

\section{A distinct ecotonal tree community exists at central African forest-savanna transitions}

Anabelle W. Cardoso*1,2 ${ }^{*}$ Imma Oliveras ${ }^{1}$, Katharine A. Abernethy ${ }^{3,4}$, Kathryn J. Jeffery ${ }^{3}$, Sarah

Glover $^{3}$, David Lehmann ${ }^{3,5}$, Josué Edzang Ndong ${ }^{5}$, Lee J.T. White ${ }^{5}$, William J. Bond ${ }^{6}$, Yadvinder Malhi ${ }^{1}$

*Corresponding author, anabellecardoso@gmail.com

${ }^{1}$ School of Geography and the Environment, U.Oxford, South Parks Road, Oxford, OX1 3QY, UK.

${ }^{2}$ Ecology and Evolutionary Biology Department, Yale University, New Haven, Connecticut, USA, 06511 .

${ }^{3}$ Biological and Environmental Sciences, Faculty of Natural Sciences, U.Stirling, Stirling, FK9LA, UK.

${ }^{4}$ Institut de Recherche en Ecologie Tropicale, CENAREST, BP843, Libreville, Gabon.

${ }_{5}^{5}$ Agence Nationale des Parcs Nationaux, BP20379, Libreville, Gabon.

${ }^{6}$ Biological Sciences Department, U. Cape Town, Cape Town, 7700, South Africa.

This article has been accepted for publication and undergone full peer review but has not been through the copyediting, typesetting, pagination and proofreading process, which may lead to differences between this version and the Version of Record. Please cite this article as Cardoso, AW, Oliveras, I, Abernethy, KA, et al. A distinct ecotonal tree community exists at central African forestsavanna transitions. Journal of Ecology 2021; 109: 1170- 1183 doi: 10.1111/1365-2745.13549

This article is protected by copyright. All rights reserved 


\section{ABSTRACT}

1. Global change is expected to increase savanna woody encroachment as well as fire spreading into forest. Forest-savanna ecotones are the frontier of these processes and can thus either mitigate or enhance the effects of global change. However, the ecology of the forest-savanna ecotone is poorly understood. In this study, we determined whether a distinct ecotonal tree community existed between forest and savanna. We then evaluated whether the ecotonal tree community was more likely to facilitate fire spreading into the forest, woody encroachment of the savanna, or the stabilisation of both forest and savanna parts of the landscape.

2. We sampled twenty-eight vegetation transects across forest-savanna ecotones in a central African forest-savanna mosaic. We collected data on the size and species of all established (basal diameter $>3 \mathrm{~cm}$ ) trees in each transect. Split moving window dissimilarity analysis detected the location of borders delineating savanna, ecotone, and forest tree communities. We assessed whether the ecotonal tree community was likely to facilitate fire spreading into the forest by burning experimental fires and evaluating shade and grass biomass along the transects. To decide if the ecotone was likely to facilitate woody encroachment of the savanna we evaluated if ecotonal tree species were forest pioneers.

3. A compositionally distinct and spatially extensive ecotonal tree community existed between forest and savanna. The ecotonal tree community did not promote fire spreading into forest and instead acted as a fire buffer, shading out flammable grass biomass from the understorey and protecting the forest from $95 \%$ of savanna fires. The ecotone helped stabilise the forest-savanna mosaic by allowing the fire-dependant savanna to burn without exposing the fire-sensitive forest to lethal temperatures.

4. The ecotonal tree community was comprised of many forest pioneer species that will promote woody encroachment in the savanna, especially if fire frequency is decreased.

SYNTHESIS: A distinct fire-buffering ecotonal tree community in this forest-savanna mosaic landscape illustrated that savanna fires are unlikely to compromise forest integrity. Conversely, 
suppression of fire in this landscape will likely lead to loss of savanna as the ecotone becomes the frontier of woody encroachment. Regular burning is essential for the preservation of this forestsavanna mosaic.

\section{SECOND ABSTRACT}

1. Le réchauffement climatique globale pourrait permettre l'expansion des savanes ligneuses sur les écosystèmes forestiers et ainsi augmenté les surfaces de propagation des feux à l'intérieur des forets. Les mosaïque forets savanes sont caractérisés par une frontière, ou écotone, démarquant ces deux compartiments. Cet écotone particulier peut alors mitiger ou amplifier les effets de ce réchauffement planétaire. Néanmoins, l'écologie de cet écotone de transition foret-savane est jusqu'alors peut étudier. Dans cette étude, nous avons déterminer l'assemblage des espèces ligneuses qui forment une communié végétale distincte, spécifique à cet écotone. Nous avons ensuite évalué et tester les propriétés de cette communauté dans le ralentissement ou la propagation des feux de savane en forêt ; son impact sur la dynamique de cette mosaïque foret-savane, avec soit une colonisation de la forêt vers la savane ou une stabilisation de ces deux composantes paysagères.

2. Nous avons échantillonné vingt-huit transects à travers ce type d'écotones de transition dans une mosaïque forêt-savane d'Afrique centrale. Nous avons recueilli des données sur la taille et les espèces de tous les arbres de plus de trois centimètres de diamètre recensé le long de chaque transects. Notre analyse de "Split moving window dissimilarity" le long de ces transects nous a permis de détecté les limites précise délimitant la communauté végétale de savane, celle propre à l' écotone et celle de la forêt. Pour observer si la communauté végétale spécifique à l'écotone de transition était susceptible de faciliter la propagation du feu dans la forêt, nous avons provoqués des feux expérimentaux et évalué l'ombre et la biomasse d'herbe le long des transects. Pour déterminer si l'écotone était susceptible de faciliter l'avancement de la foret sur la savane, nous avons évalué si les espèces d'arbres formant la communauté végétale spécifique à l'écotone de transition étaient des espèces pionnières ou colonisatrice.

3. Notre étude met en lumière l'existence d'un assemblage d'espèces ligneuses formant une communauté spécifique à cet écotone de transition foret-savane. Cette communauté n'a pas favorisé la propagation du feu en forêt et a au contraire agi comme un coupe-feu grâce à l'ombre qu'elle projette

This article is protected by copyright. All rights reserved 
sur la biomasse d'herbe potentiellement inflammable du sous-bois. Dans notre étude, l'écotone testé a protégé la foret de 95\% des feux de savane expérimentaux. Cet écotone permet de stabiliser la dynamique de la mosaïque foret savane ; en permettant à la savane de se régénérer par brulis et en protégeant la forêt des incendies et des températures létales pour les arbres.

4. La communauté d'espèces végétales de l'écotone était composée de nombreuses espèces pionnières forestières qui favorisent l'avancement de la forêt sur la savane, surtout si la fréquence des feux est diminuée.

SYNTHÈSE : Dans ce paysage mosaïqué forêt-savane, une communauté d'espèces végétales distincte propre à l'écotone de transition existe qui tamponnent l'impact du feux sur la forêt. Notre étude démontre alors que les feux de savane sont peu susceptibles de compromettre l'intégrité de la forêt. Inversement, la suppression des incendies dans ce paysage entraînera alors une perte de l'écosystème de savane car l'écotone permet le recrutement d'espèces ligneuses colonisatrices, favorisant l'expansion de la forêt. Un brûlage régulier semble donc être requis pour la préservation de cette mosaïque forêt-savane.

\section{KEY WORDS}

Alternative stable states, Ecotone, Transition, Edge effects, Ecological threshold, Functional traits, Fire, Forest-savanna mosaic

\section{INTRODUCTION}

In Africa, forest and savanna cover approximately half of the continent's land surface (11\% and 34\% respectively) and provide invaluable ecosystem services at local and global scales to millions of people (Grace et al., 2006; Lewis et al., 2009; Olsson \& Ouattara, 2013; Parr et al., 2014; Moore et al., 2017). Global change threatens the provision of these ecosystem services by eroding forest and savanna ecosystem function through changes to the natural fire regime (Heubes et al., 2011; Willis et al., 2013; van Nes et al., 2014; Seddon et al., 2016; Scheiter et al., 2019). When fire-sensitive forests burn more regularly they are invaded by grasses and become more "savanna-like", and when firedependant savannas burn less regularly they are invaded by trees and become more "forest-like". Neither a grass-invaded forest nor a woody-encroached savanna possess the extensive biodiversity or 
ecological functionality of their intact counterparts (Balch et al., 2008, 2015; Bond \& Parr, 2010; Ratnam et al., 2011; Veldman \& Putz, 2011; Silvério et al., 2013; Brando et al., 2014; Parr et al., 2014; Veldman et al., 2015; Veldman, 2016; McCleery et al., 2018). The forest-savanna ecotone is the most vulnerable part of each biome. The ecotone is where forest is closest to savanna fires and savanna is closest to a pool of potentially invasive tree species (Favier et al., 2004b; Balch et al., 2008; Aleman \& Staver, 2018; Barlow et al., 2019). The ecology of the forest-savanna ecotone dictates whether this landscape feature mitigates or enhances the negative effects of global change. The forest-savanna ecotone is therefore a critical, yet poorly understood, component of tropical landscape dynamics.

Ecotones are "zones of tension" (Odum, 1959) between adjacent communities. In the case of forestsavanna ecotones, this "tension" arises, to a large extent, from the opposing fire- and light- driven feedbacks that maintain forest and savanna (Hoffmann et al., 2012a; Oliveras \& Malhi, 2016). The closed canopy of the forest reduces light levels in the understorey, creating a fire suppressing microclimate, shading out flammable grasses, and keeping the forest virtually fire-free (Biddulph \& Kellman, 1998; Hennenberg et al., 2008; Hoffmann et al., 2012b; Charles-Dominique et al., 2018). In contrast, the open canopy of the savanna allows ample light to reach the understorey, promoting a drier microclimate, the accumulation of flammable grasses, and frequent burning (Bond \& Van Wilgen, 1996; Scholes \& Archer, 1997; Biddulph \& Kellman, 1998; Hoffmann et al., 2012b). When fire-dependant savannas border fire-sensitive forests, there is a risk that fire burns from the savanna into the forest and destroys the forest's functionality (Silvério et al., 2013; Balch et al., 2015). Conversely, without regular burning savannas become invaded by trees and can no longer provide their full suite of ecosystem services (Parr et al., 2014; Veldman et al., 2015; Veldman, 2016; Pausas $\&$ Bond, 2020). For a forest-savanna mosaic to remain stable and not become dominated by only forest or savanna, there must be a mechanism within the forest-savanna ecotone that allows savannas to burn while keeping forests fire-free. We therefore expect the ecotone to experience a distinct fireand light- regime which is intermediate to that of forest and savanna (Charles-Dominique et al., 2018), and we expect a distinct ecotonal tree community to have filled this niche (Odum, 1959). Previous work on forest-savanna ecotones in Africa has noted the presence of potential "margin 
specialist tree species" (White \& Abernethy, 1997; Charles-Dominique et al., 2018; Abiem et al., 2020) but empirical study, quantitative description, and ecological exploration of the hypothetical ecotonal community is lacking.

When the fire- and light- driven stabilising feedback loops that enable forest and savanna co-existence become weakened by anthropogenic global change both forest and savanna become degraded ecosystems (Parr et al., 2014; Brando et al., 2019a). Forests become drier, more flammable, and more likely to transform into grass-invaded systems with increases in temperature, the frequency of drought conditions, deforestation, and fragmentation (IPCC, 2007; Balch et al., 2008, 2015; Veldman \& Putz, 2011; James \& Washington, 2013; Silvério et al., 2013; Brando et al., 2014; Barlow et al., 2019; Fonseca et al., 2019). Conversely, savannas have reduced fire frequency and become invaded by trees as increases in atmospheric carbon dioxide favour the growth of trees over grasses and when changes in local land use and management decrease burned area (Kgope et al., 2009; Mitchard et al., 2011; Bond \& Midgley, 2012; Buitenwerf et al., 2012; Andela \& Van Der Werf, 2014; Durigan \& Ratter, 2016; Stevens et al., 2016, 2017; Andela et al., 2017). The forest-savanna ecotone can increase forest's vulnerability to being burned if it is comprised of tree species whose canopies have a high level of light penetration and allow flammable fine fuel to accumulate at the forest edge (Hoffmann et al., 2012b; Balch et al., 2015; Charles-Dominique et al., 2018). The forest-savanna ecotone can accelerate savanna woody encroachment if it is comprised of forest pioneer species and acts as a source of new tree recruits into the savanna during periods of fire suppression (Favier et al., 2004b,a; Parr et al., 2012). It is also possible that the forest-savanna ecotone is comprised of species that neither facilitate fire spread into forest, nor invade savannas. In this case, the ecotone would mitigate against the negative effects of global change by effectively separating the fire- and light- regimes of forest and savanna and thus facilitating co-existence by strengthening the resilience of both systems.

Grass invasion and woody encroachment are especially likely to occur in bi-stable landscapes where both forest and savanna are climatically possible ecosystem states (Hirota et al., 2011; Staver et al., 2011). In bi-stable landscapes, the forest savanna ecotone is abrupt, occurring on the scale of a few metres (Bond \& Parr, 2010). Forest-savanna mosaics, which cover 10\% of Africa (Parr et al., 2014), 
are the quintessential example of a bi-stable landscape with abrupt ecotones. While some fluctuation in the balance between forest and savanna is expected in mosaics (Maley, 2002; Aleman et al., 2018), current global change has the potential to cause sudden and irreversible state shifts in both forest and savanna (Hirota et al., 2011). This shift is more likely, at least in the medium term, to decrease functional habitat than it is to increase the functional core area of either forest or savanna (Silvério et al., 2013; Veldman et al., 2015). Forest-savanna mosaics are thus the ideal study system for investigating the ecology of the forest-savanna ecotone.

The few available studies on sharp forest-savanna ecotones in bi-stable landscapes have focused on the compositional and functional differences between forest and savanna (Hennenberg et al., 2005; Hoffmann et al., 2012a; Dantas et al., 2013; Cardoso et al., 2016), how the forest edge is moving over time (Favier et al., 2004b; Ibanez et al., 2013b), or how far the depth of edge influence of one vegetation type (forest or savanna) extends into the other (Hennenberg et al., 2008; Hoffmann et al., 2012b; Ibanez et al., 2013a). The only studies that explicitly explore the ecotonal tree community usually do so at forest-derived grassland transitions, for example where forest has been cleared for agriculture. These studies usually find the ecotonal tree community to be an ephemeral successional one (Oliveira et al., 2004; Laurance et al., 2006; Tabarelli et al., 2008; Peres et al., 2010) and associated with negative "edge influence" effects (Tabarelli et al., 1999; Harper et al., 2005). To our knowledge, no similar studies have been undertaken at "natural" forest-savanna ecotones which persist over long periods of time. One exception is the Cerradão of Brazil, a transitional dry woodland which is distinct from forest and savanna in composition, structure, and function (Eiten, 1972; Ratter \& Dargie, 1992; Ratter et al., 1996; Coelho et al., 2016; Reis et al., 2017). The Cerradão has been extensively described, however since this ecosystem occurs in large patches across a gradient of transition from forest to savanna rather than in a narrow band at abrupt forest-savanna ecotones in bistable landscapes, we differentiate the Cerradão from the ecotonal tree community that is the focus of this study.

In this study, our objective was to assess whether a distinct ecotonal tree community exists between forest and savanna in a bi-stable landscape, and whether this community is likely to reduce or enhance 
the resilience of the landscape to global change. We sampled twenty-eight vegetation transects across ecotones in a fire-managed forest-savanna mosaic in Lopé National Park, Gabon. Using tree community composition of the savanna, across the ecotone, and into the forest, we first determined whether a distinct ecotonal tree community could be detected between forest and savanna; or if the ecotone was simply a mixture of forest and savanna species that form no distinct community. If a distinct ecotonal tree community could be detected, we then aimed to determine if the ecotonal tree community was more likely to facilitate a) woody encroachment of the savanna (i.e. comprised of forest pioneer species), b) fire spreading into the forest (i.e. comprised of open-canopied species which facilitated the accumulation of grass biomass in the understorey), or c) neither, thus facilitating stabilisation of the mosaic.

\section{MATERIALS AND METHODS}

\section{Study site}

This study was carried out in the northern forest-savanna mosaic of Lopé National Park (LNP), Gabon (0.2S, 11.6E) (Fig. 1). The mosaic is characterised by an abundance of abrupt ecotones between Lower Guineo-Congolian rainforest (White, 1983) and Middle Ogooué savannas (van de Weghe, 2011) (Fig. S1). In LNP, mean daily minimum and maximum temperatures were $22{ }^{\circ} \mathrm{C}$ and $28{ }^{\circ} \mathrm{C}$ in the forest (1984-2018) and $22{ }^{\circ} \mathrm{C}$ and $32{ }^{\circ} \mathrm{C}$ in the savanna (2002-2018). Mean relative humidity was 98.2\% in the forest and 92.7\% in the savanna over the same time period (Bush et al., 2019; Tutin et al., 2019). Mean annual rainfall is $1466 \mathrm{~mm}$ (1984-2018), which falls mainly outside of the dry seasons (Bush et al., 2019; Tutin et al., 2019). There is a short (mid-December to mid-February) and a long (mid-June to mid-September) dry season, with controlled fires occurring in the long dry season as part of LNP's conservation plan (Jeffery et al., 2014). Controlled burning has occurred since 1993 but there is evidence that fire has been a feature of the landscape for at least 5000 years (White, 2001).

\section{Vegetation transects}

We set up 28 vegetation transects across forest-savanna ecotones. The transects covered a variety of fire frequencies, ranging from the savanna having been burned less than three times in the past ten 
years to having been burned up to three times in the past three years (Fig. 1). The majority of transects were burned between one and three times in the past three years, which is considered the optimal fire frequency for a high rainfall African savanna in terms of increasing grass species richness, evenness, and diversity (Smith et al., 2013). All transects were at least 100m apart.

Transects were $2 \mathrm{~m}$ wide and varied in length $(37 \mathrm{~m}-48 \mathrm{~m})$ depending on the sharpness of the ecotone. Transects started by covering $25 \mathrm{~m}$ of field-defined savanna, then crossed the entire fielddefined ecotone, and finally covered 10m of field-defined forest (Fig. S2). Field-defined delineations between savanna, ecotone, and forest were used to establish the length of the transect in order to ensure adequate sampling and were not used in data analyses. In the field, we defined savanna to be where grass cover was continuous, tree canopy cover was discontinuous, and visibility at eye level was at least $5 \mathrm{~m}$. The savanna ended and the ecotone began where grass cover became discontinuous and tree canopy cover became continuous. The ecotone was characteristically easy to identify as it was a "wall of leaves", with visibility at eye level being less than $5 \mathrm{~m}$ and a high level of continuity between the understorey and mid canopy layers. The ecotone ended and the forest began where the midstorey became open and visibility increased to more than $5 \mathrm{~m}$, but grass biomass remained low and the tree canopy remained closed. In order to minimise bias, field-defined vegetation types were delineated based on consensus of at least three researchers.

We sampled transects in adjacent $1 \mathrm{~m}$ long blocks, each $2 \mathrm{~m}$ wide. In each block, we measured all woody stems with a basal diameter (measured at $10 \mathrm{~cm}$ above ground) $>3 \mathrm{~cm}$ ("adult stems"), noting their species and basal diameter. Additionally, we measured all woody stems in a nested sampling strip $20 \mathrm{~cm}$ wide on the left-hand side of the transect with a basal diameter $<3 \mathrm{~cm}$ and a height $>30 \mathrm{~cm}$ (“juvenile stems"), noting their species and basal diameter. All analyses were limited to a focus group of tree and shrub species, hereafter referred to as focus tree species for simplicity, which were those whose adult stems represented $90 \%$ of the stems and more than $88 \%$ of the basal area sampled across

all transects. We tested for spatial autocorrelation of species composition between transect sites using a Mantel test (Sokal \& Rohlf, 1995). The Mantel test tested for significant correlation between a Bray-Curtis dissimilarity matrix derived from adult stem counts for each of the focus tree species and 
a geographic matrix of the distances between transect sites using the non-parametric Spearman correlation method (function mantel in R package vegan (Oksanen et al., 2019). As the Mantel test was performed on two distance matrices only, our analysis did not violate its assumptions (Guillot \& Rousset, 2013; Legendre et al., 2015).

\section{Identifying the ecotonal tree community}

To assess whether a distinct ecotonal tree community existed between forest and savanna, we looked for evidence of more than one border along the length of the transects. A border is the boundary between two communities at which point the magnitude of change between them is the greatest (Hennenberg et al., 2005). To detect borders between tree communities along the length of the transects we used split moving window dissimilarity analysis (SMWDA) (Ludwig \& Cornelius, 1987; Cornelius \& Reynolds, 1991). Using a moving window approach, SMWDA calculated the dissimilarity of adjacent half-windows along a transect and identified borders as locations where significant peaks in dissimilarity occurred (Ludwig \& Cornelius, 1987; Cornelius \& Reynolds, 1991). Dissimilarities were calculated relative to an expected mean (as determined by a Monte Carlo procedure with 100 replicates), and then normalised (Z-score) (Hennenberg et al., 2005; Erdős et al., 2014). Borders along the transect, or significant peaks in dissimilarity, occurred when the Z-score exceeded the one-tailed 95\% confidence interval (Z-score>1.645) (Hennenberg et al., 2005). The mean dissimilarity of five half-window sizes (1-5m) was used to reduce the scale dependency of the results (Cornelius \& Reynolds, 1991; Hennenberg et al., 2005; Erdős et al., 2014). The R script upon which our SMWDA was based is published by Erdos et al. (2014).

To determine dissimilarities, we compared squared Euclidean distances calculated using a presenceabsence matrix. Presence-absence matrices were produced by merging the transects, since there were too few adult stems in individual transects to detect meaningful differences between tree communities. Merging effectively increased the area, and thus number of stems sampled, in each transect and gave us a better representation of community composition by increasing the probability of sampling rare or large individuals (Staver, 2017). Merging was performed twice to account for the differing lengths of the transects: transects were first aligned at their savanna edge to look for a

This article is protected by copyright. All rights reserved 
significant border between savanna and ecotone tree communities, and then they were aligned on their forest edge to look for a significant border between forest and ecotone tree communities (Fig. S3). To merge the transects, sampling blocks were numbered sequentially, with block 1 being first in the savanna and then in the forest. Numbered blocks were aligned and merged with one another so that their species composition was a composite of all transects sampled. From this merged transect, a presence-absence matrix was created.

A border will have some length associated with it over which substantial change occurs. Once borders were detected, the length of each border was calculated using moving window regression analysis (MWRA). MWRA calculated the rate of change (i.e. slope) of Z-scores along the transect (Walker et al., 2003; Hennenberg et al., 2005). The slope value for each Z-score was calculated on the Z-score itself and the two Z-scores on either side of it using a moving window approach (Walker et al., 2003; Hennenberg et al., 2005). These slope values were used to verify the location of the borders detected in SMWDA. True borders should be both significant peaks in SMWDA and turning points (slope $=0$ ) in MWRA (Hennenberg et al., 2005). Slope values were also used to determine the length of each border, which was the distance between the maximum and minimum of the slope values either side of the border (Walker et al., 2003; Hennenberg et al., 2005). If two borders were detected and their lengths did not overlap, then three distinct vegetation communities were present. For example, if one border occurred between $25 \mathrm{~m}$ and $27 \mathrm{~m}$ along a transect and a second border occurred between $35 \mathrm{~m}$ and $37 \mathrm{~m}$ along the same transect, then these two borders did not overlap and savanna, ecotone, and forest communities were present. Alternatively, if one border occurred between $25 \mathrm{~m}$ and $35 \mathrm{~m}$ and a second border occurred between $27 \mathrm{~m}$ and $39 \mathrm{~m}$, these two borders overlapped and only one true border was present and separated only two distinct vegetation communities: forest and savanna.

Based on the location and length of the detected borders individual transects were divided into sections of savanna, ecotone, and forest. For example, if the border between savanna and ecotone was detected at $25 \mathrm{~m}$ along the merged transect, all individual transects were divided into savanna and ecotone at that point. This delineation superseded the field-based delineation of vegetation communities. We then determined whether each of the focus tree species demonstrated a preference

This article is protected by copyright. All rights reserved 
for savanna, ecotone, or forest by comparing observed and expected frequencies using $\chi^{2}$ tests (function pchisq in package stats, R Development Core Team, 2018). Observed frequencies were the counts of each tree species in each vegetation type, and expected frequencies were calculated under the assumption that the stem density of a species was constant across savanna, ecotone, and forest parts of the transect. Significant deviation from the expected frequencies was when $p<0.05$. When $\chi^{2}$ was significant, we assessed the source of significance by calculating post-hoc the Pearson

standardised residual for savanna, ecotone, and forest using the formula: $\frac{\text { observed-expected }}{\sqrt{\text { expected }}}$. A significant residual indicated that the species had a significantly higher than expected density of stems in that vegetation type. Residuals were significant when they were greater than 2.128 , and $p$ was adjusted using the Bonferroni correction for multiple comparisons within each species (Sharp, 2015).

\section{Investigating the ecology of the forest-savanna ecotone}

To determine whether the ecotonal tree community is likely to facilitate woody encroachment of the savanna, we assessed whether it contained forest pioneer species. We considered pioneer species to be those that were a dominant component in colonising and early successional forest types. Colonising forest was where savanna used to occur but fire has been supressed for $>20$ years and extensive woody encroachment had occurred as a result (White, 2001; Cuni-Sanchez et al., 2016). Tree canopy cover, density, and diversity was higher in colonising forest than in savanna, although $\mathrm{C} 4$ grasses were still present in the understorey, albeit at a lower biomass than in the savanna (White, 2001; Cuni-Sanchez et al., 2016). Young, or early successional, forest succeeds colonising forest. Young forest encompassed both monodominant forest of Aucoumea klaineana in tightly packed even-aged stands, and young Marantaceae forest dominated by A. klaineana and Lophira alata. Young forest types had a more closed canopy and larger stems than colonising forest, although the dominant species were also present in the colonising forest, specifically Aucoumea klaineana, Lophira alata, and Sacoglottis gabonensis (White, 2001; Cuni-Sanchez et al., 2016). The final successional stage sampled was the "mature forest", which is succeeds young forest (White, 2001; Cuni-Sanchez et al., 2016). Mature forest included mixed mature Marantaceae forest and mature montane forest, both of which had a more closed canopy, larger stems, and a higher species diversity than the young forest (White, 2001; Cuni-Sanchez et al., 2016). Increases in tree size, canopy closure, and species diversity

This article is protected by copyright. All rights reserved 
support that these forest types are successional to one another. The successional classification was supported by the spatial distribution of the forest types within the broader LNP landscape, with younger successional stages occurring closer to the savanna and later successional stages occurring further away, towards the core forest (White, 2001).

We examined tree census data collected in twenty-two 0.08ha plots in LNP between 2013 and 2017 (original description of plots and sampling methodology can be found in White (1995)). In each census plot, all trees with a diameter at breast height $>5 \mathrm{~cm}$ had their trunk diameter measured and their species noted. Due to the difference in minimum stem size sampled in the census plots $(>5 \mathrm{~cm}$ diameter at breast height) and in the transects of this study ( $>3 \mathrm{~cm}$ at $10 \mathrm{~cm}$ above ground level), we compared only stems $>5 \mathrm{~cm}$ from this study to the census plots. However, this still results in slight differences in the minimum cut-off size, and therefore we did not place a strong emphasis on relatively small differences in stem count and basal area.

To assess whether the ecotonal tree community is likely to facilitate regular fire spread into the forest, we estimated how much shade it was casting on the understorey, how much grass biomass was present, how often fire spread from the savanna into the ecotone, and whether the structure of the ecotone more closely resembled the forest or the savanna. As a proxy for shading, we estimated canopy leaf area index (LAI, canopy leaf area per unit of ground area), where higher LAI values indicated lower levels of understorey light availability. We calculated canopy LAI from hemispherical photographs taken along the length of each transect (every $5 \mathrm{~m}$ in the field-defined savanna and forest and every $1 \mathrm{~m}$ in the field-defined ecotone) (details available in Cardoso et al., 2018). To estimate grass biomass, we used a disc pasture meter calibrated for the site (details available in Cardoso et al., 2018), taking one reading in each block of each transect. We characterised the fire regime of the ecotone by lighting experimental fires in the savannas of 20 of the 28 transect sites. Fires occurred in July and September 2016 as part of the normal conservation management protocol of LNP (Jeffery et al., 2014; Cardoso et al., 2018). After each fire, we examined the burn scars to determine how far along the length of each transect the fire had burned. From this, we calculated how frequently fire penetrated the ecotone and the forest, relative to the savanna. To assess the structure of the ecotone 
we calculated the foliage density index at $0.5 \mathrm{~m}, 1 \mathrm{~m}, 1.5 \mathrm{~m}, 2 \mathrm{~m}$, and $2.5 \mathrm{~m}$ above ground every $5 \mathrm{~m}$ along the transect in the field-defined savanna and forest and every $2.5 \mathrm{~m}$ in the field-defined ecotone. The foliage density index is a measure of vegetation density and is calculated as the inverse of the distance at which a white A5 piece of paper is no longer visible to the observer, who is holding their eye at the desired level above ground (Bond et al., 1980). When vegetation is dense at a certain height above ground the foliage density index is higher because the piece of paper becomes obscured by leaves at a closer distance to the observer.

To assess how functionally distinct ecotone tree species were from forest and savanna and to draw additional inferences about ecotone ecology, we measured four key functional traits in each of the focus tree species: relative bark thickness, bark accumulation rate, wood density, and leaf mass per area (LMA). Relative bark thickness ( $\mathrm{mm}$ of bark per mm of trunk diameter) is a measure of a tree's ability to tolerate regular burning, with thicker bark increasing stem insulation from lethal temperatures, and thinner bark increasing the susceptibility of a tree to top-kill during burning (Hoffmann et al., 2003; Bova \& Dickinson, 2005; Midgley et al., 2011; Hempson et al., 2014). Bark accumulation rate, or the allometric coefficient of bark, is a measure of the speed of bark production. Rates $<1$ indicate a disproportionally higher investment in bark at smaller trunk diameters, $>1$ disproportionally higher at larger trunk diameters, and $\approx 1$ proportional investment in bark with diameter (Jackson et al., 1999). LMA (g per $\mathrm{cm}^{2}$ ) and wood density (g of dry wood mass per $\mathrm{cm}^{3}$ of wood volume) are both indicators of growth rate and longevity, with lower LMA and wood density both associated with pioneer species which have fast growth and shorter lifespans (Wright et al., 2004; Poorter \& Bongers, 2006; Kunstler et al., 2015).

Bark thickness was measured (using digital callipers) at three locations on one $4 \mathrm{~cm}^{2}$ sample of bark removed from the trunk at $30 \mathrm{~cm}$ above the ground. Relative bark thickness was determined by dividing the median value of the three thickness measurements by the trunk diameter at the point of sampling (Lawes et al., 2013; Corrêa Scalon et al., 2019). Mean relative bark thickness was calculated on at least nine individuals per species. We determined the bark accumulation rate for each species to be equal to the slope of a linear model fitted to bark thickness as a function of trunk

This article is protected by copyright. All rights reserved 
diameter (both variables ln transformed) (Jackson et al., 1999; Hoffmann et al., 2003) (Fig. S4). LMA was calculated by scanning leaves (excluding petioles) (using desktop scanner Canon LiDE 120) and converting scans to leaf pixel area via post-hoc image analysis in MatLab (v8.0) (Blonder, 2015) before dividing this by leaf mass (determined after oven drying at $70^{\circ} \mathrm{C}$ to constant weight). LMA was determined for each species on a minimum of 5 mature leaves per tree and 3 trees per species. Wood density was calculated on three trees per species. For each tree, the mean oven dry mass of three twigs ( $\pm 1-2 \mathrm{~cm}$ diameter) was divided by the volume of each twig (after bark was removed; Marthews et al., 2014). All traits were sampled on trees outside of the transects.

\section{RESULTS}

In the twenty-eight forest-savanna ecotone transects, sixteen tree species comprised more than $90 \%$ of the stems and more than $88 \%$ of the basal area sampled. These focus tree species were, in order of decreasing abundance (Table S1): Crossopteryx febrifuga, Millettia versicolor, Diospyros dendo, Ouratea myrioneura, Antidesma vogelianum, Psychotria vogeliana, Barteria fistulosa, Cryptosepalum staudtii, Lophira alata, Sarcocephalus latifolius, Cnestis ferruginea, Saccoglottis gabonensis, Xylopia aethiopica, Diospyros zenkeri, Gomphia flava, and Aucoumea klaineana. All analyses presented were performed only with these focus tree species. The transect sites were not spatially autocorrelated in terms of species composition (Mantel test, $\mathrm{R}=-0.03, \mathrm{p}=0.63$ ).

To assess whether a distinct ecotonal tree community could be detected between savanna and forest, split moving window dissimilarity analysis (SMWDA) and moving window regression analysis (MWRA) were applied to tree community composition data. SMWDA and MWRA detected two significant borders (where Z-score $>1.96$ and a turning point exists) along forest-savanna ecotone transects. The lengths of these borders (i.e. the distance between the maximum and minimum MWRA slope value either side of each border) were non-overlapping, indicating that three distinct tree communities were present: savanna, ecotone, and forest. The border between the savanna and ecotone was located $27 \mathrm{~m}$ along the transects (Fig. 2a) and the border between the ecotone and the forest was located 36m along the transects (Fig. 2b). Using the detected border lengths to delineate the tree communities, savanna was found in the first $26 \mathrm{~m}$ along the transects, the ecotone from $26 \mathrm{~m}$ to $36 \mathrm{~m}$, 
and forest from $36 \mathrm{~m}$ to $48 \mathrm{~m}$. The ecotone was, on average, $10 \mathrm{~m}$ wide. Using the width of the ecotone and geographical information software, we calculated that the ecotone has a length of $339.6 \mathrm{~km}$ in the study site, and thus occupies $3.4 \mathrm{~km}^{2}$, or $7 \%$ of the area occupied by savanna in the study site (Fig. S5).

$\chi^{2}$ tests were used to classify the focal tree species into ecotone, savanna, and forest communities. $\chi^{2}$ tests showed thirteen of the sixteen focus tree species to have significantly higher than expected densities in either savanna, ecotone, or forest sections of the transect (Fig. 3, Table S2). The ecotone community comprised ten tree species: M. versicolor, A. vogelianum, $P$. vogeliana, B. fistulosa, C. staudtii, L. alata, C. ferruginea, S. gabonensis, and A. klaineana. The savanna community comprised one tree species, C. febrifuga, while the forest comprised three tree species, D. dendo, D. zenkeri, and $G$. flava. Three species were not able to be classified into any of the three communities: $O$. myrioneura, X. aethiopica, and S. latifolius.

To determine whether the ecotonal tree community was comprised of forest pioneer species, we compared the abundance of each ecotonal tree species in the ecotone section of transects sampled in this study with their abundance in census plots sampled in colonising, young, and mature forest types (Fig. 4, Table S3). For stems $>5 \mathrm{~cm}$ diameter, $M$. versicolor was the single most dominant species in the ecotone, however was found to contribute negligible proportions $(<0.03)$ to total stem counts and basal area in colonising, young, and mature forest types. Similarly, C. ferruginea, P. vogeliana, and C. staudtii were also only found to occur only in the ecotone (although C. ferruginea did have one stem in the colonising forest plots) types. A. vogelianum and B. fistulosa were both dominant species in the colonising forest but had low to no presence in young or mature forest plots. The three species contributing the largest proportion to total basal area in the ecotone, L. alata, S. gabonensis, and A. klaineana were also dominant species in the colonising forest plots. In fact, $L$. alata contributed nearly a third of all stems and just under $40 \%$ of all basal area in the colonising forest while $A$. klaineana was the most dominant species in the young forest, comprising nearly three quarters of the basal area sampled in these plots. None of the ecotonal tree species dominated in the mature forest,

This article is protected by copyright. All rights reserved 
although $L$. alata and A. klaineana both contributed a substantial proportion (>0.03) to the total basal area.

All three tree species classified as being part of the forest community in this study contributed proportionally more stems and an approximately equal proportion of basal area to the young and mature forest types as they did to the ecotone; and contributed negligible proportions of stems and basal area to the colonising forest (Fig. 4). The tree species classified as being part of the savanna community in this study were absent from young and mature forest, but present in colonising forest.

To assess whether the ecotonal tree community was likely to facilitate the spread of savanna fires into the forest, we examined tree canopy leaf area index (LAI), grass biomass, the occurrence of fire along each of the forest-savanna transects, and vegetation structure through the foliage density index. We found that the ecotonal tree community was efficient at blocking out light and suppressing grass biomass (Fig. 5). Tree canopy LAI was significantly lower and grass biomass significantly higher in the savanna than in the ecotone or the forest (LAI: $\chi^{2}=206, p<0.0001, \mathrm{df}=2$, mean: savanna $=1.7$, ecotone $=4.6$, forest $=4.8$; grass biomass: $\chi^{2}=898, \mathrm{p}<0.0001, \mathrm{df}=2$, mean (tons $/ \mathrm{ha}$ ): savanna $=3.9$, ecotone $=0.6$, forest $=0$ ). Although LAI was not significantly different between the ecotone and the forest, there were significant differences in vegetation structure between the two communities. The ecotone community had the highest mean foliage density index at all measured heights above ground level. Notably, the ecotone's foliage density index was significantly higher than the savanna at all measured heights, and significantly higher than the forest at heights $0.5 \mathrm{~m}$ and $1 \mathrm{~m}$. The ecotonal tree community was exposed to fire eight of the twenty times that experimental fires were lit in the savanna, while fire reached the forest only once. The ecotonal tree community thus experienced fire at less than half the frequency of the savanna, but eight times the frequency of the forest.

To assess whether the ecotonal tree species were functionally more similar to savanna or to forest tree species we assessed their functional traits. Ecotonal tree species had a relative bark thickness, bark accumulation rate, wood density, and LMA that was intermediate to forest and savanna species (Fig.

6, Table S4). Wilcoxon rank sum tests found that ecotonal tree species had significantly higher 
relative bark thickness $(\mathrm{W}=30, \mathrm{p}=0.007)$ and bark accumulation rates $(\mathrm{W}=29, \mathrm{p}=0.014)$ than forest tree species, but did not differ from forest species in terms of LMA or wood density ( $p>0.3)$. No statistical comparison between ecotonal and savanna species was possible due to the savanna tree community only comprising one tree species.

\section{DISCUSSION}

A compositionally and structurally distinct ecotonal tree community existed in the forest-savanna mosaic of Lopé National Park, Gabon. This community was a significant component of the studied landscape. The ecotonal tree community did not facilitate the savannisation of forest by promoting the spread of fire into the forest. Rather, it stabilised the mosaic by allowing the savanna to burn regularly without exposing the forest to lethal temperatures by acting as a fire buffer between savanna and forest. However, the ecotonal tree community will likely accelerate woody encroachment of the savanna, especially if fire frequency in this landscape was to decrease, because it supported a pool of colonising tree species.

The first aim of this study was to establish whether a distinct ecotonal tree community existed between forest and savanna, or if the forest-savanna ecotone was simply a mixture of forest and savanna tree species. We found strong evidence that the ecotonal tree community was compositionally distinct, as two non-overlapping borders, or discontinuities in tree species composition, were present along transects. The ecotone occupied a relatively narrow (10m) belt between forest and savanna, however the fragmented nature of the mosaic gave ecotone significant linear extent. The ecotone was found to occupy a relatively large area (just under a tenth of the amount of area occupied by savanna) and was thus an ecologically relevant component of the forestsavanna mosaic.

The second aim of this study was to determine whether the ecotonal tree community was more likely to facilitate woody encroachment into savanna, fire spreading into forest, or the stability of the forestsavanna mosaic by facilitating neither. For a forest-savanna mosaic to be stable, patches of forest and savanna should always exist, even if their spatial arrangement fluctuates through time (Maley, 2002;

This article is protected by copyright. All rights reserved 
Aleman et al., 2018). We found strong evidence that the ecotonal tree community facilitated the continued coexistence of forest and savanna in this landscape by buffering the forest from $95 \%$ of the fires that burned in the savanna, thus separating forest and savanna disturbance regimes. The ecotone's fire buffering capacity was likely driven by its distinct structure. The ecotone's foliage density index was higher than the savanna at all measured heights above ground, quantitively confirming our field observations that the ecotone can be easily recognised as a "wall of leaves". This "wall of leaves" intercepted light and severely limited the grass biomass in the understorey. The limitation of grassy fuels in a belt between savanna and forest is a crucial component of the fire buffer the ecotonal tree community creates and thus a key driver of mosaic stability.

The ability of the ecotonal tree community to separate the disturbance regimes of forest and savanna is likely resilient through time. Not only does the ecotone limit grassy fuels, but the ecotonal tree community also had significantly thicker bark and accumulated bark at a significantly faster rate than forest tree species. A faster bark accumulation rate means that ecotonal tree species will become fire resistant at a small size, and potentially younger age, than forest tree species (Jackson et al., 1999; Hoffmann et al., 2012a). Thicker bark also allows the ecotone to maintain buffering capacity over time as thicker bark allows trees to insulate their stems from lethal temperatures and increases their ability to tolerate repeated burning (Bova \& Dickinson, 2005; Midgley \& Bond, 2011; Hoffmann et al. 2012a). These bark traits contribute to the resilience of the buffering capacity of ecotonal tree community through time, which is crucial as recent ground data from the study site confirm warming and drying are at a critical level for forest survival (Bush et al., 2019). Similar patterns have been found in Afromontane forest, where fire-resistant tree species in forest patches buffered the core forest population from the fire in the surrounding grassy matrix (Adie et al., 2017; Abiem et al., 2020). This buffering helped maintain forest function and diversity over long periods of time.

The presence of a resilient, fire-buffering ecotonal tree community suggests that, under current conditions, savanna can be regularly burned without risk to forest. This finding is especially important in places where fire has historically been seen as a "threat" to forest and suppressed as a result (e.g. Madagascar or Brazil) (Alvarado et al., 2018). Fire suppression policies can have disastrous 
consequences for biodiversity and ecosystem function (Parr et al., 2014; Bond, 2016; Stevens et al., 2017; Pausas \& Bond, 2020), as has been the case in the Cerrado of Brazil which has suffered widespread encroachment as a result of fire suppression policies (Durigan \& Ratter, 2016; Rosan et al., 2019). It is very important to note that not all fires in open landscapes are safe for forests. If a forest-savanna mosaic lacks a fire-buffering ecotonal community it may indicate that the "savanna" is actually degraded grassy patches that arose within the forest matrix as a result of deforestation and subsequent fires (Ratnam et al., 2011). Under these circumstances, the remaining forested area is vulnerable to further damage and would need to be protected from burning in order to recover (Brando et al., 2012, 2019a,b; Balch et al., 2015; Barlow et al., 2019; Staver et al., 2019). Assessment of the fire buffering capacity of the ecotonal tree community is thus essential prior to burning, especially as forests become more flammable under predicted increases in the frequency and severity of drought conditions (IPCC, 2007; Verhegghen et al., 2016).

Although the ecotonal tree community stabilises the forest-savanna mosaic when the savanna is burned regularly, the same community will likely accelerate woody encroachment of the savanna if fire were to be suppressed. The ecotonal tree community contained many forest pioneer species, as evidenced by their high abundances and basal areas in colonising forest census plots as well as by descriptions of their ecology in the literature (Table S1, (White \& Abernethy, 1997). This pool of pioneer species, while normally largely kept within the ecotone by regular burning, will likely quickly advance into the savanna if fire frequency or intensity is reduced. Evidence of woody encroachment emanating from the ecotone can already be seen in parts of the study site (Jeffery et al., 2014), potentially as a result of fire intensity decreasing nearer to the forest edge (Cardoso et al., 2018). Woody encroachment is a major conservation challenge across tropical Africa and likely to only become worse in the future with increasing global atmospheric carbon dioxide and increasing rainfall in many parts of central Africa expected to favour the growth of trees over grasses (Kgope et al., 2009; Scheiter \& Higgins, 2009; Staver et al., 2011; Bond \& Midgley, 2012; Buitenwerf et al., 2012; James \& Washington, 2013; Stevens et al., 2016, 2017; Case \& Staver, 2018). The potential ability of the ecotone to transform into the frontier of woody encroachment emphasises how close forest- 
savanna mosaics may be to a sudden and practically irreversible state shift, and how important regular burning is for preventing this.

Although beyond the scope of this study, it is also interesting to consider what the ecology of the forest-savanna ecotone might indicate about the evolution and antiquity of forest-savanna mosaics. Forest-savanna ecotones likely first arose 4-8 Mya, when forests contracted and gave way to islands of C4 grassy systems (Osborne, 2008). These ecotones would likely have presented a novel niche in the landscape in which a stable community may have developed. Much like the ecotonal tree community we observed in this study, new communities are more likely to be populated with existing species that already have the necessary adaptations to survive than they are to be filled with newly evolved species (Donoghue, 2008). It is therefore possible that the distinct ecotonal tree community found in this study is as old as the forest-savanna ecotone itself. If this were the case, the ecotonal tree community may hold clues as to how forest tree species were first able to leave the forest and enter the grasslands of Africa to create the savannas we see today.

In conclusion, this study highlighted the unique ecology of the forest-savanna ecotone in a forestsavanna mosaic in central Africa. By acting as a fire buffer between savanna and forest the forestsavanna ecotone helped stabilise the mosaic. Without this buffer, it would be increasingly difficult to continue to burn savanna without risk to the forest. If fire frequency in this landscape were to be reduced the ecotonal tree community would likely transform from a stabilising buffer to the frontier of woody encroachment. Regular burning of tropical savannas is thus essential to maintain ecosystem function and habitat diversity in forest-savanna mosaics. By describing an ecologically distinct ecotonal tree community, we contribute to an existing body of work that emphasises the high conservation value of forest-savanna mosaics (Parr et al., 2014). Repetition of this study across tropical forest-savanna mosaics to establish under which circumstances similar patterns are found would be a fascinating area for future research.

\section{ACKNOWLEDGEMENTS}

This article is protected by copyright. All rights reserved 
Agence Nationale des Parcs Nationaux (ANPN), ANPN director of science Dr A.F. Koumba Pambo, and ANPN field assistants G.A. Kamba, J. Dibakou, E. Dimoto, A.D. Bousseba, N.E. Milamizokou, P.A. Dimbonda, M.C. Koumba, B. Moussavou, and S. Nzoma. T. Charles-Dominique, E. Berenguer, S. Archibald, C. Staver, and M. Macias-Fauria for helpful discussions. Anonymous reviewers for constructive feedback. Project research expenses and AWC were supported by U. Oxford's Hertford Mortimer-May scholarship; AWC was also supported by the Commonwealth Scholarship Commission and the Oppenheimer Fund; KA, KJ and DL were supported by the U. Stirling; LJTW, KJ and JEN by ANPN; and YM by ERC grant ERC-2013-AdG-321131-GEMTRAITS and the Jackson Foundation.

\section{DATA AVILABILITY STATEMENT}

All data are archived at Oxford University Libraries, DOI: 10.5287/bodleian:VJXGQj09d

\section{AUTHOR'S CONTRIBUTIONS}

AWC, IO, KA, YM, WB developed ideas, hypotheses, and the experimental setup; AWC lead the data collection and analysis and KJ, DL, JEN assisted with fieldwork and provided substantial feedback on methodology; LJTW, SG contributed data. AWC lead the writing, and IO, KA, WB and YM made significant contributions to the writing; all authors provided constructive comments on the draft.

\section{FIGURE LEGENDS}

Figure 1: Map of a) Gabon within Africa, b) Lopé National Park within Gabon, c) the study site within the broader region of Lopé National Park, and d) and the twenty-eight transect sites within the forest-savanna mosaic of the study site (Agence Nationale des Parcs Nationaux, 2006).

Figure 2: Split Moving Window Dissimilarity Analysis (SMWDA) and Moving Window Regression Analysis (MWRA) for the twenty-eight forest-savanna transition transects. Transects were aligned for the analysis on their savanna side to best detect the border between savanna and ecotone (A) and were aligned on the forest side to best detect the border between ecotone and forest (B). * s indicate

This article is protected by copyright. All rights reserved 
detected border locations (turning points), $\uparrow$ and adjoining lines indicate lengths of borders (maximum and minimum of regression slopes in MWRA). Horizontal dotted lines at $y=1.645$ and $y=0$ mark the significance thresholds for SMWDA and turning points in MWRA respectively. The detected savanna, ecotone, and forest tree communities are shown by shaded blocks.

Figure 3: The mean abundance of each focal tree species along the length of the twenty-eight forestsavanna transition transects. Parts of the line that are solid indicate that the species had significantly higher than expected abundances in that vegetation type ( $\chi^{2} \mathrm{p}$-value was significant and residual $>2.13$ ). Vegetation types are shown by shaded blocks, savanna is shaded green, ecotone is shaded blue, and forest is shaded purple. Species that had significant positive residuals in only one of the three vegetation types were classified into that tree community, with coloured boxes around each species name indicating its community: green boxes are savanna species, blue boxes are ecotonal species, purple boxes are forest species, and grey boxes are species which were not classified into any community.

Figure 4: The proportion that each of the sixteen focal tree species contribute to the a) sum of basal area and b) count of stems sampled in each of the forest types. This study sampled twenty-eight forest-savanna transition transects ("ecotone"), while the other forest types ("colonising forest", "young forest", "mature forest") were sampled in twenty-two 0.08ha plots by White et al. (unpublished). Data is only shown for stems that are $>5 \mathrm{~cm}$ diameter at the point of measurement (10 cm above the ground for the ecotone, and at breast height for the other three forest types). The pathway for forest expansion into savanna is that fire suppressed savanna becomes colonizing forest, which is succeeded by young forest, which is succeeded by mature forest (White, 2001).

Figure 5: a) Mean grass biomass and leaf area index along the length of the twenty-eight forestsavanna transition transects. The limits of each vegetation type are shown by shaded blocks. Mean grass biomass was 3.9 tons/ha in savanna, 0.1 tons/ha in the ecotone, and 0.0 tons/ha in the forest. Mean leaf area index was 1.6 in the savanna, 4.6 in the ecotone, and 4.8 in the forest). Mean foliage density index for each vegetation type at increasing heights above ground level. Different letters 
indicate significant differences between vegetation types at the height above ground level according to Kruskal-Wallis tests.

Figure 6: The median and interquartile range of the scaled value for each functional trait measured for each group of species. Significant differences between the ecotone and forest groups of species were tested using Wilcoxon rank sum tests, which showed that bark accumulation rate ( $\mathrm{W}=29$, $\mathrm{p}=0.014$ ) and relative bark thickness $(\mathrm{W}=30, \mathrm{p}=0.007)$ were the only traits that differed significantly between the two groups. The savanna group of species contained only one sampled and therefore could not be statistically compared to the other two groups.

\section{FIGURE 1}

This article is protected by copyright. All rights reserved 


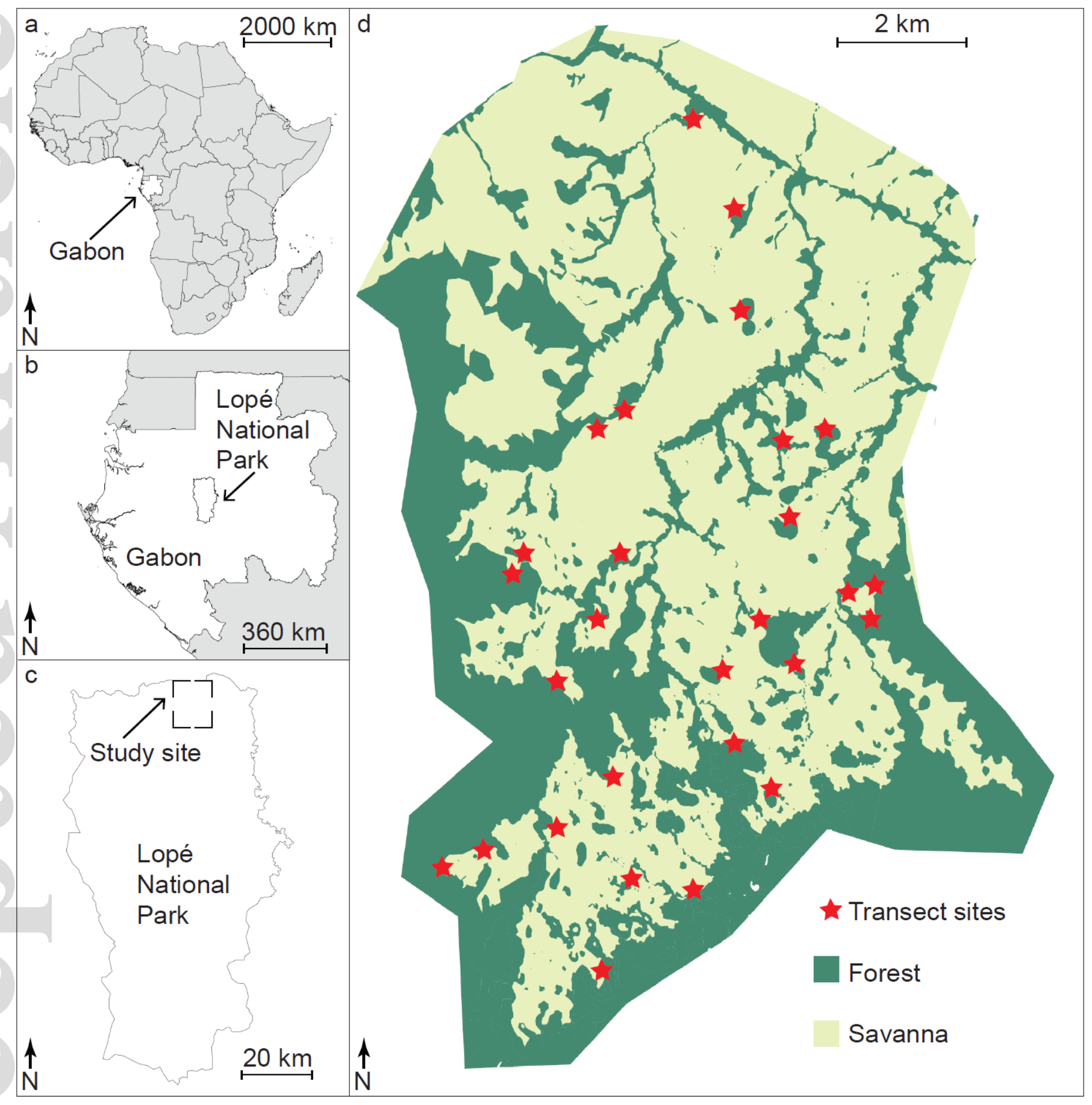

This article is protected by copyright. All rights reserved 

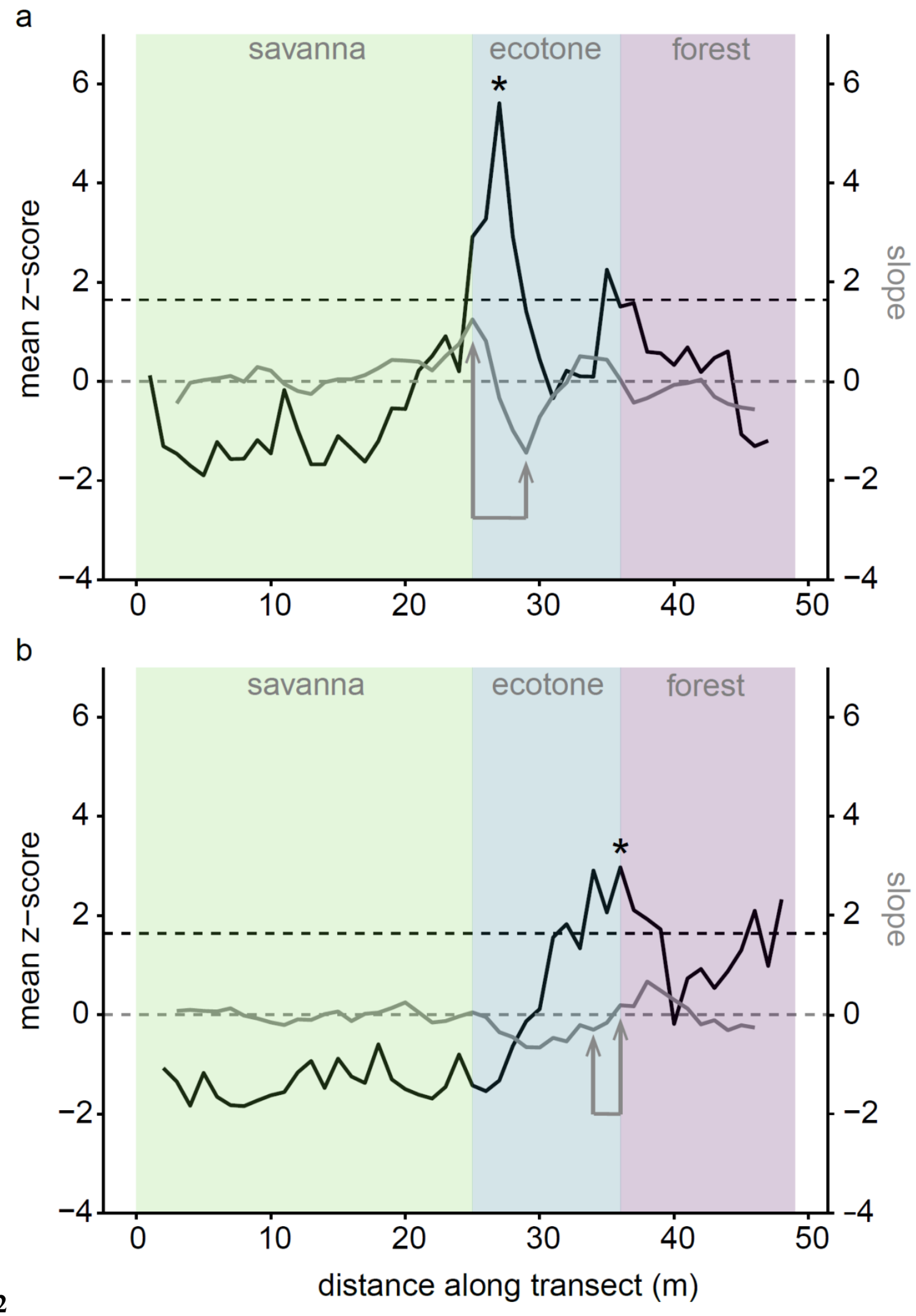

FIGURE 2 
FIGURE 3

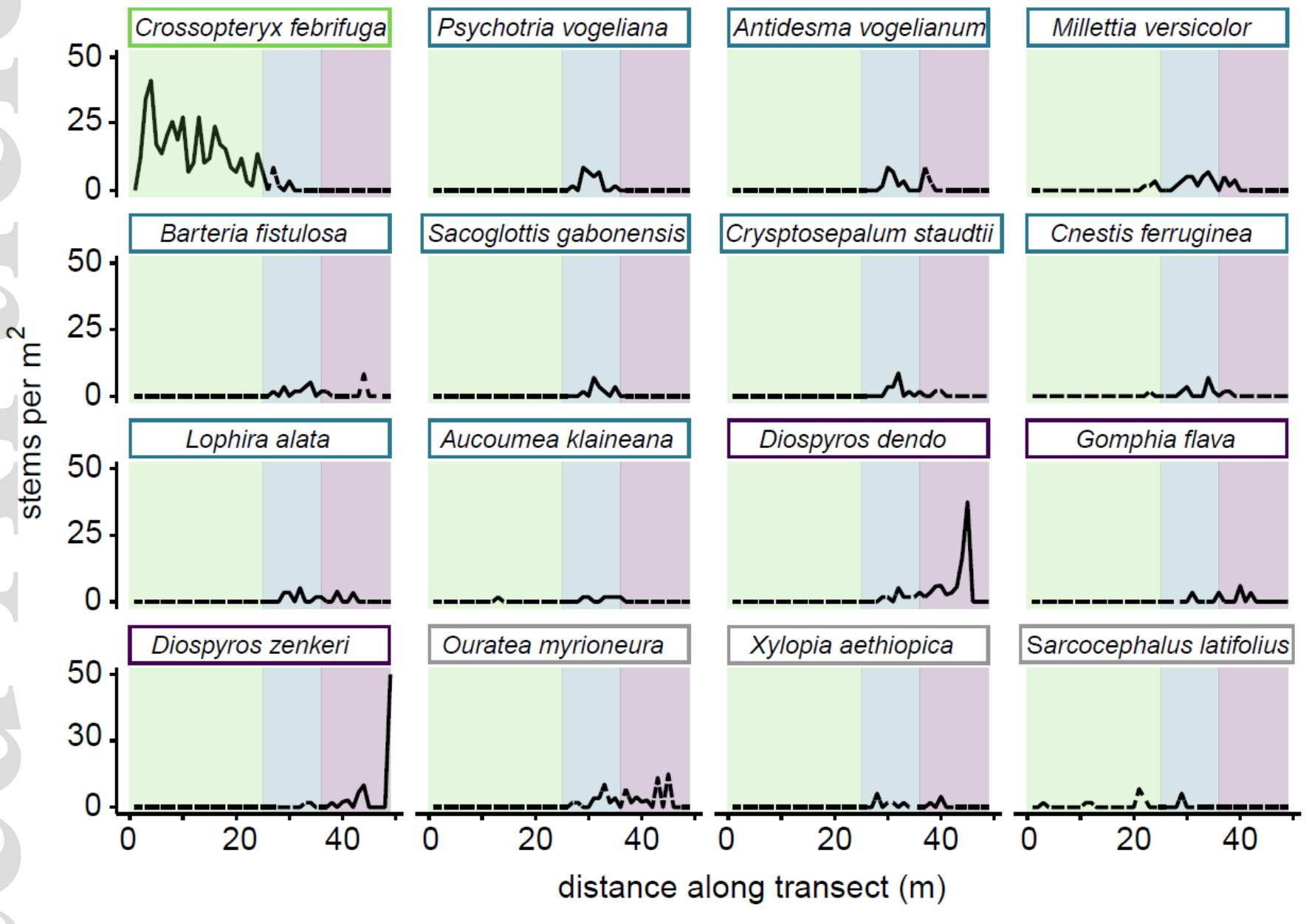

This article is protected by copyright. All rights reserved 
FIGURE 4

a
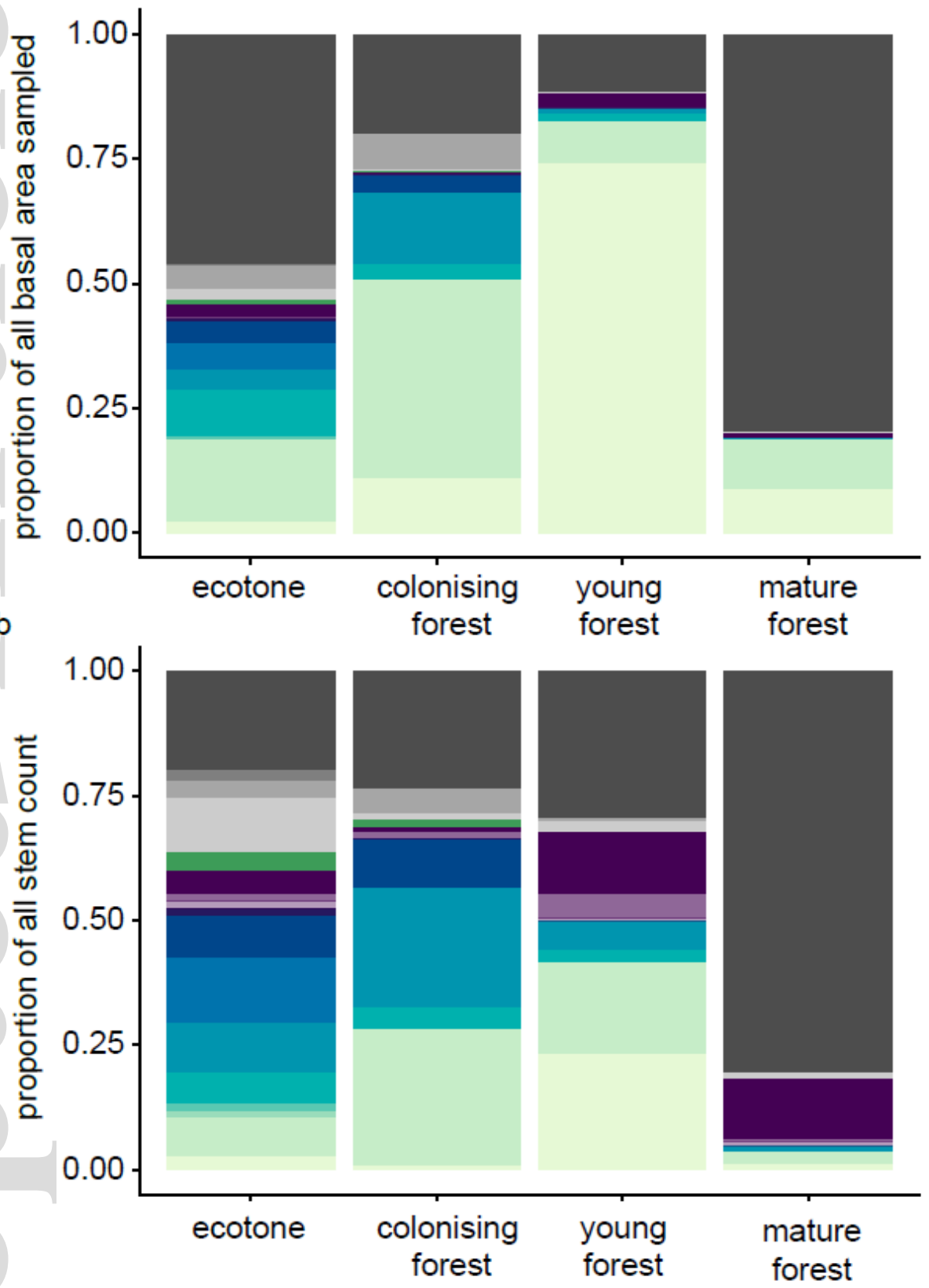

Other species

Sarcocephalus latifolius

Xylopia aethiopica

Ouratea myrioneura

Crossopteryx febrifuga

Diospyros dendo

Gomphia flava

Diospyros zenkeri

Psychotria vogeliana

Antidesma vogeliana

Millettia versicolor

Barteria fistulosa

Sacoglottis gabonensis

Cryptosepalum staudtii

Cnestis ferruginea

Lophira alata

Aucoumea klaineana

This article is protected by copyright. All rights reserved 
FIGURE 5

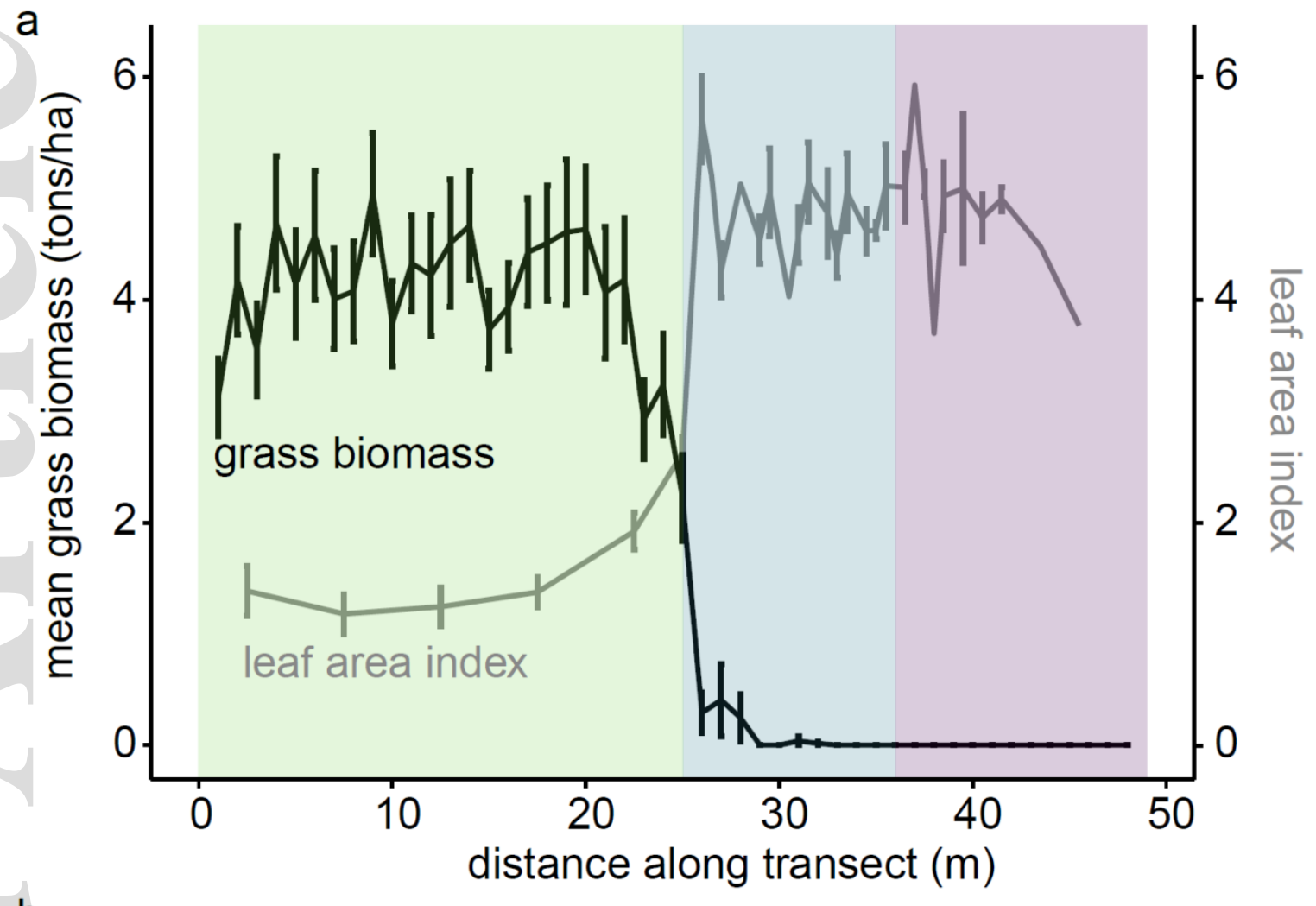

b

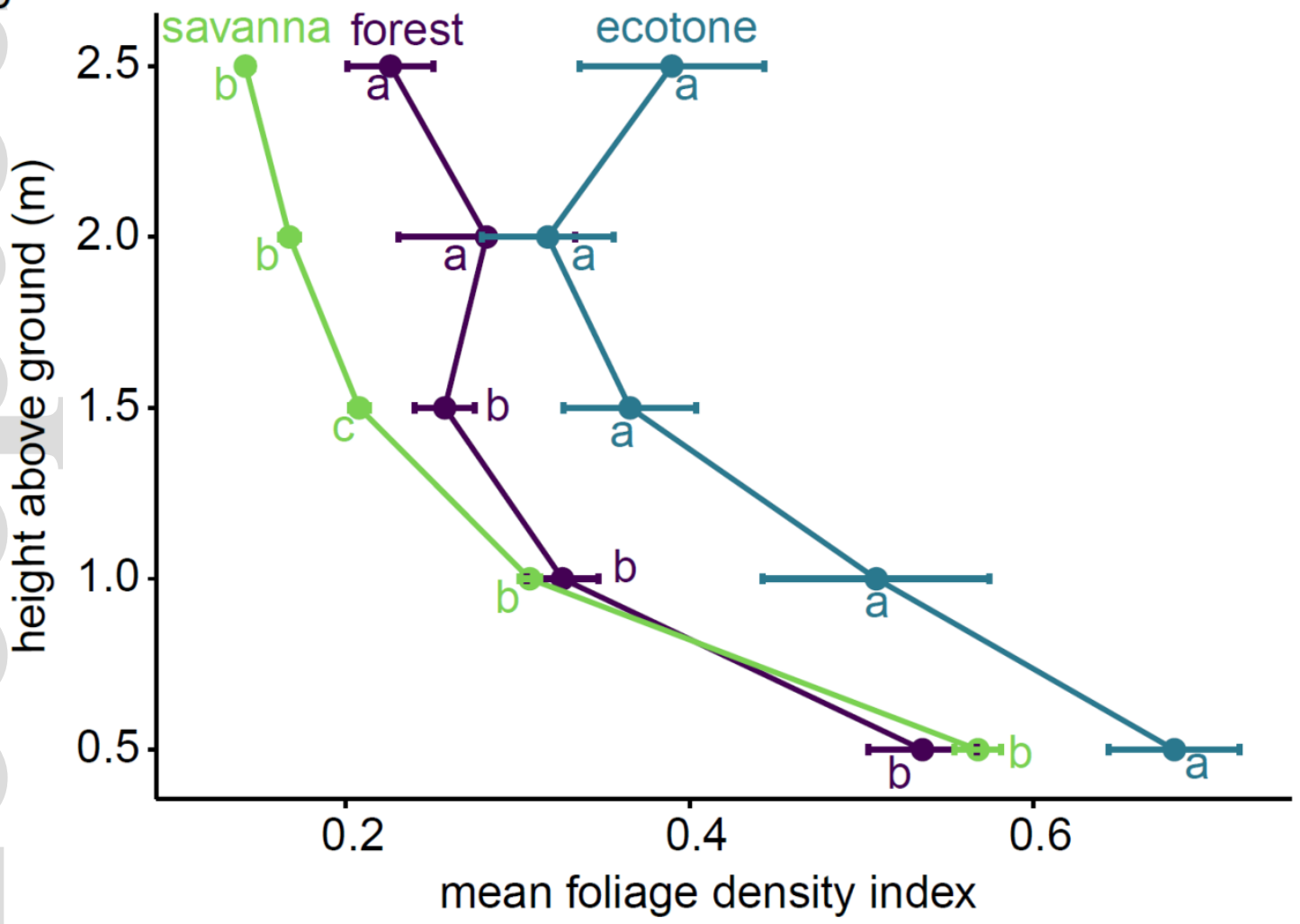

This article is protected by copyright. All rights reserved 
FIGURE 6

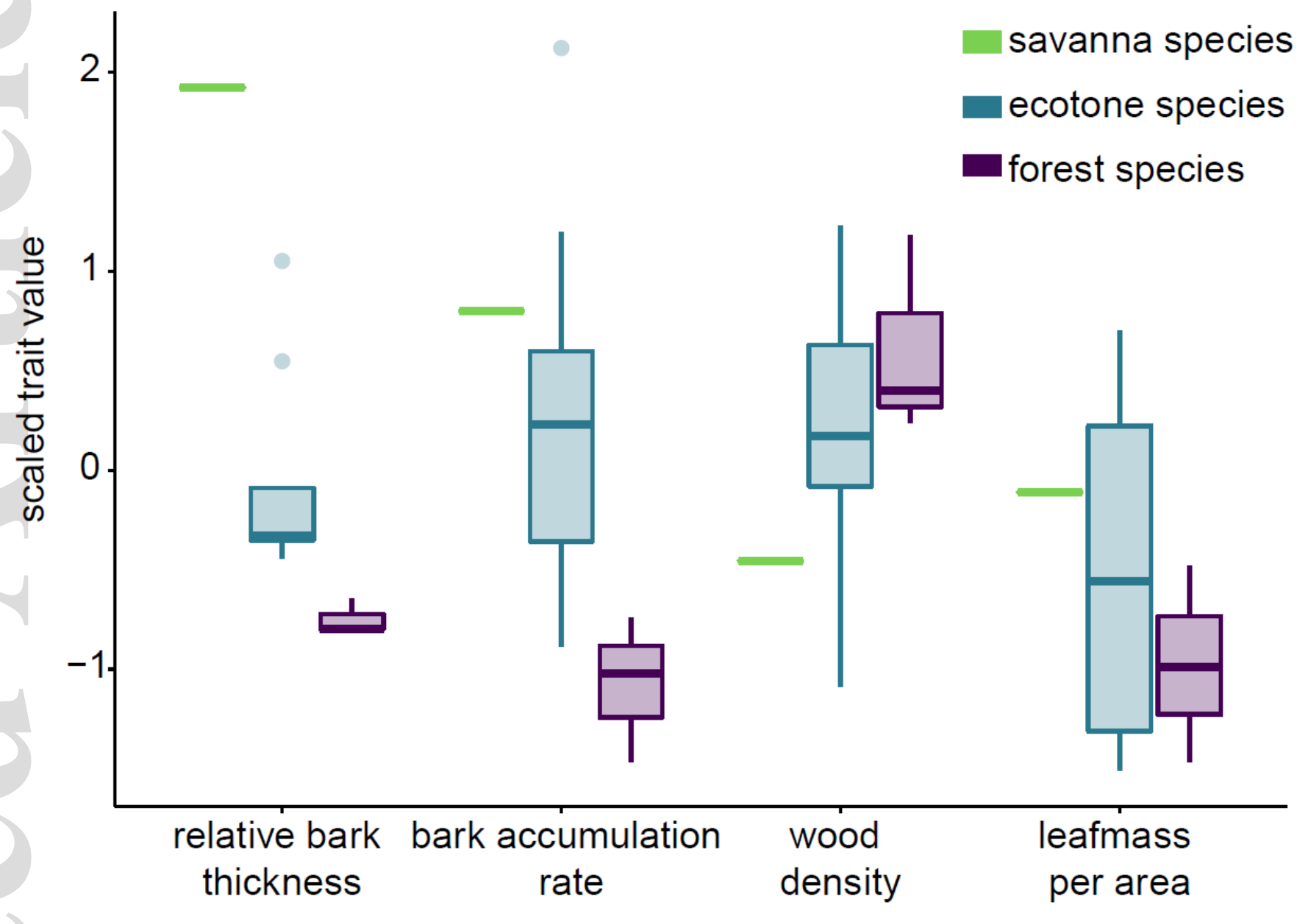

\section{REFERENCES}

Abiem I, Arellano G, Kenfack D, Chapman H. 2020. Afromontane Forest Diversity and the Role of

This article is protected by copyright. All rights reserved 
Grassland-Forest Transition in Tree Species Distribution. Diversity 30: 1-19.

Adie H, Kotze DJ, Lawes MJ. 2017. Small fire refugia in the grassy matrix and the persistence of Afrotemperate forest in the Drakensberg mountains. Scientific Reports: 1-10.

Agence Nationale des Parcs Nationaux. 2006. Forest-savanna cover derived from 30m AVHRR Radar imagery, INTerra 1998 updated with ground measurement 2006. SEGC Map Database.

Aleman JC, Jarzyna MA, Staver AC. 2018. Forest extent and deforestation in tropical Africa since 1900. Nature Ecology and Evolution 2: 26-33.

Aleman JC, Staver AC. 2018. Spatial patterns in the global distributions of savanna and forest. Global Ecology and Biogeography 1: 1-12.

Alvarado ST, Silva TSF, Archibald S. 2018. Management impacts on fire occurrence: A comparison of fire regimes of African and South American tropical savannas in different protected areas. Journal of Environmental Management 218: 79-87.

Andela N, Morton DC, Giglio L, Chen Y, Werf GR Van Der, Kasibhatla PS, Defries RS, Collatz

GJ, Hantson S, Kloster S, et al. 2017. A human-driven decline in global burned area. Science 356: $1356-1362$.

Andela N, Van Der Werf GR. 2014. Recent trends in African fires driven by cropland expansion and El Niño to la Niña transition. Nature Climate Change 4: 791-795.

Balch JK, Brando PM, Nepstad DC, Coe MT, Silvério D, Massad TJ, Davidson EA, Lefebvre P, Oliveira-Santos C, Rocha W, et al. 2015. The Susceptibility of Southeastern Amazon Forests to Fire: Insights from a Large-Scale Burn Experiment. BioScience 65: 893-905.

Balch JRK, Nepstad DC, Brando PM, Curran LM, Portela O, de Carvalho O, Lefebvre P. 2008. Negative fire feedback in a transitional forest of southeastern Amazonia. Global Change Biology 14: $2276-2287$.

Barlow J, Berenguer E, Carmenta R, Filipe F. 2019. Clarifying Amazonia's burning crisis. Global Change Biology: 1-3.

Biddulph J, Kellman M. 1998. Fuels and fire at savanna-gallery forest boundaries in southeastern Venezuela. Journal of Tropical Ecology 14: 445-461.

Blonder B. 2015. Code for leaf size (area) and shape estimation from scanned images. Github: https://github.com/bblonder/leafarea.

This article is protected by copyright. All rights reserved 
Bond WJ. 2016. Ancient grasslands at risk. Science 351: 120-122.

Bond W, Ferguson M w., Forsyth G. 1980. Small mammals and habitat structure along altitudinal gradients in the southern Cape mountains. South African Journal of Zoology 15: 34-43.

Bond WJ, Midgley GF. 2012. Carbon dioxide and the uneasy interactions of trees and savannah grasses. Philosophical Transactions of the Royal Society B: Biological Sciences 367: 601-612.

Bond WJ, Parr CL. 2010. Beyond the forest edge: Ecology, diversity and conservation of the grassy biomes. Biological Conservation 143: 2395-2404.

Bond WJ, Van Wilgen B. 1996. Fire and Plants. In: Population and Community Biology Series 14. London: Chapman and Hall, 1-227.

Bova AS, Dickinson MB. 2005. Linking surface-fire behavior, stem heating, and tissue necrosis. Canadian Journal of Forest Research 35: 814-822.

Brando PM, Balch JK, Nepstad DC, Morton DC, Putz FE, Coe MT, Silverio D, Macedo MN, Davidson EA, Nobrega CC, et al. 2014. Abrupt increases in Amazonian tree mortality due to drought-fire interactions. Proceedings of the National Academy of Sciences 111: 6347-6352.

Brando PM, Nepstad DC, Balch JK, Bolker B, Christman MC, Coe M, Putz FE. 2012. Fireinduced tree mortality in a neotropical forest: The roles of bark traits, tree size, wood density and fire behavior. Global Change Biology 18: 630-641.

Brando PM, Paolucci L, Ummenhofer CC, Ordway EM, Hartmann H, Cattau ME, Rattis L, Medjibe V, Coe MT, Balch J. 2019a. Droughts, Wildfires, and Forest Carbon Cycling: A Pantropical Synthesis. Annual Review of Earth and Planetary Sciences 47: 555-581.

Brando PM, Silvério D, Maracahipes-Santos L, Oliveira-Santos C, Levick SR, Coe MT, Migliavacca M, Balch JK, Macedo MN, Nepstad DC, et al. 2019b. Prolonged tropical forest degradation due to compounding disturbances: Implications for $\mathrm{CO} 2$ and $\mathrm{H} 2 \mathrm{O}$ fluxes. Global Change Biology 25: 2855-2868.

Buitenwerf R, Bond WJ, Stevens N, Trollope WSW. 2012. Increased tree densities in South Africa savannas: More than 50 years of data suggests CO2 as a driver. Global Change Biology 18: 675-684. Bush ER, Jeffery K, Bunnefeld N, Tutin C, Musgrave R, Moussavou G, Mihindou V, Malhi Y, Lehmann D, Ndong JE, et al. 2019. Ground data confirm warming and drying are at a critical level for forest survival in western equatorial Africa. PeerJ.

This article is protected by copyright. All rights reserved 
Cardoso AW, Medina-Vega JA, Malhi Y, Adu-bredu S, Ametsitsi GK, Djagbletey G, Van

Langevelde F, Veenendaal E, Oliveras I. 2016. Winners and losers : tropical forest tree seedling survival across a West African forest - savanna transition. Ecology and Evolution: 1-13.

Cardoso AW, Oliveras I, Abernethy KA, Jeffery KJ, Glover S, Lehmann D, Ndong JE, White

LJT, Bond WJ, Malhi Y. 2020. Data from: A distinct ecotonal tree community exists at central African forest-savanna transitions. Oxford University Libraries. DOI: 10.5287/bodleian:VJXGQj09d Cardoso AW, Oliveras I, Abernethy KA, Jeffery KJ, Lehmann D, Edzang Ndong J, McGregor

I, Belcher CM, Bond WJ, Malhi YS. 2018. Grass Species Flammability, Not Biomass, Drives Changes in Fire Behavior at Tropical Forest-Savanna Transitions. Frontiers in Forests and Global Change 1: 6.

Case MF, Staver AC. 2018. Soil texture mediates tree responses to rainfall intensity in African savannas. New Phytologist 219: 1363-1372.

Charles-Dominique T, Midgley GF, Tomlinson KW, Bond WJ. 2018. Steal the light: shade vs fire adapted vegetation in forest-savanna mosaics. New Phytologist.

Coelho PA, Santos PF, de Paiva Paula E, Apgaua DMG, Madeira BG, Menino GC de O, Nunes YRF, Santos RM, Tng DYP. 2016. Tree succession across a seasonally dry tropical forest and forest-savanna ecotone in northern Minas Gerais, Brazil. Journal of Plant Ecology 10: rtw091. Cornelius JM, Reynolds JF. 1991. On Determining the Statistical Significance of Discontinuities with Ordered Ecological Data Stable. Ecology 72: 2057-2070.

Corrêa Scalon M, Maia Chaves Bicalho Domingos F, Jonatar Alves da Cruz W, Marimon Júnior BH, Schwantes Marimon B, Oliveras I. 2019. Diversity of functional trade-offs enhances survival after fire in Neotropical savanna species. Journal of Vegetation Science.

Cuni-Sanchez A, White LJT, Calders K, Jeffery KJ, Abernethy K, Burt A, Disney M, Gilpin M, Gomez-Dans JL, Lewis SL. 2016. African savanna-forest boundary dynamics: A 20-year study. PLOS ONE 11: 1-23.

Dantas V de L, Batalha MA, Pausas JG. 2013. Fire drives functional thresholds on the savanna forest transition. Ecology 94: 2454-2463.

Donoghue MJ. 2008. A phylogenetic perspective on the distribution of plant diversity. Proceedings of the National Academy of Sciences 105: 11549-11555.

This article is protected by copyright. All rights reserved 
Durigan G, Ratter JA. 2016. The need for a consistent fire policy for Cerrado conservation. Journal of Applied Ecology 53: 11-15.

Eiten G. 1972. The cerrado vegetation of Brazil. The Botanical Review 38: 201-341.

Erdős L, Bátori Z, Tölgyesi CS, Körmöczi L. 2014. The Moving Split Window (MSW) Analysis in Vegetation Science - An Overview. Applied Ecology and Environmental Reseach 12: 787-805.

Erdos L, Zalatnai M, Bátori Z, Körmöczi L. 2014. Transitions between community complexes: A case study analysing gradients through mountain ridges in South Hungary. Acta Botanica Croatica 73: $63-77$.

Favier C, Chave J, Fabing A, Schwartz D, Dubois MA. 2004a. Modelling forest-savanna mosaic dynamics in man-influenced environments: Effects of fire, climate and soil heterogeneity. Ecological Modelling 171: 85-102.

Favier C, De Namur C, Dubois MA. 2004b. Forest progression modes in littoral Congo, Central Atlantic Africa. Journal of Biogeography 31: 1445-1461.

Fonseca MG, Alves LM, Aguiar APD, Arai E, Anderson LO, Rosan TM, Shimabukuro YE, de Aragão LEO e. C. 2019. Effects of climate and land-use change scenarios on fire probability during the 21st century in the Brazilian Amazon. Global Change Biology 25: 2931-2946.

Grace J, José JS, Meir P, Miranda HS, Montes RA. 2006. Productivity and carbon fluxes of tropical savannas. Journal of Biogeography 33: 387-400.

Guillot G, Rousset F. 2013. Dismantling the Mantel tests. Methods in Ecology and Evolution 4: 336344.

Harper KA, Macdonald SE, Burton PJ, Chen J, Brosofske KD, Saunders SC, Euskirchen ES, Roberts DAR, Jaiteh MS, Esseen P-A. 2005. Edge Influence on Forest Structure and Composition in Fragmented Landscapes\rInfluencia del Borde sobre la Composición y Estructura de Bosques en Paisajes Fragmentados. Conservation Biology 19: 768-782.

Hempson GP, Midgley JJ, Lawes MJ, Vickers KJ, Kruger LM. 2014. Comparing bark thickness:

Testing methods with bark-stem data from two South African fire-prone biomes. Journal of Vegetation Science 25: 1247-1256.

Hennenberg KJ, Goetze D, Kouamé L, Orthmann B, Porembski S. 2005. Border and ecotone detection by vegetation composition along forest-savanna transects in Ivory Coast. Journal of

This article is protected by copyright. All rights reserved 
Vegetation Science 16: 301.

Hennenberg KJ, Goetze D, Szarzynski J, Orthmann B, Reineking B, Steinke I, Porembski S. 2008. Detection of seasonal variability in microclimatic borders and ecotones between forest and savanna. Basic and Applied Ecology 9: 275-285.

Heubes J, Kühn I, König K, Wittig R, Zizka G, Hahn K. 2011. Modelling biome shifts and tree cover change for 2050 in West Africa. Journal of Biogeography 38: 2248-2258.

Hirota M, Holmgren M, Van Nes EH, Scheffer M. 2011. Global Resilience of Tropical Forest and Savanna to Critical Transitions. Science 334: 232-235.

Hoffmann WA, Geiger EL, Gotsch SG, Rossatto DR, Silva LCR, Lau OL, Haridasan M, Franco AC. 2012a. Ecological thresholds at the savanna-forest boundary: how plant traits, resources and fire govern the distribution of tropical biomes. Ecology Letters 15: 759-768.

Hoffmann WA, Jaconis SY, Mckinley KL, Geiger EL, Gotsch SG, Franco AC. 2012b. Fuels or microclimate? Understanding the drivers of fire feedbacks at savanna-forest boundaries. Austral Ecology 37: 634-643.

Hoffmann WA, Orthen B, Vargas Do Nascimento PK. 2003. Comparative fire ecology of tropical savanna and forest trees. Functional Ecology 17: 720-726.

Ibanez T, Hély C, Gaucherel C. 2013a. Sharp transitions in microclimatic conditions between savanna and forest in New Caledonia: Insights into the vulnerability of forest edges to fire. Austral Ecology 38: 680-687.

Ibanez T, Munzinger J, Gaucherel C, Curt T, Hély C. 2013b. Inferring savannah-rainforest boundary dynamics from vegetation structure and composition: A case study in New Caledonia. Australian Journal of Botany 61: 128-138.

IPCC. 2007. Climate Change 2007: The Physical Science Basis. Contribution of Working Group I to the Fourth Assessment Report of the Intergovernmental Panel on Climate Change (S Solomon, D Qin, M Manning, Z Chen, M Marquis, KB Averyt, M Tignor, and HL Miller, Eds.). Cambridge University Press, New York.

Jackson JF, Adams DC, Jackson UB. 1999. Allometry of Constitutive Defense: A Model and a Comparative Test with Tree Bark and Fire Regime. The American Naturalist 153: 614-632.

James R, Washington R. 2013. Changes in African temperature and precipitation associated with

This article is protected by copyright. All rights reserved 
degrees of global warming. Climatic Change 117: 859-872.

Jeffery KJ, Korte L, Palla F, White LJT, Abernethy K a. 2014. Fire Management in a Changing Landscape : a case study from Lopé National Park. Parks 20: 35-48.

Kgope BS, Bond WJ, Midgley GF. 2009. Growth responses of African savanna trees implicate atmospheric [CO2] as a driver of past and current changes in savanna tree cover. Austral Ecology 35: 451-463.

Kunstler G, Falster D, Coomes DA, Hui F, Kooyman, Robert M, Laughlin DC, Poorter L, Vanderwel M, Vieilledent G, Wright SJ, et al. 2015. Plant functional traits have globally consistent effects on competition. Nature: 1-15.

Laurance WF, Nascimento HEM, Laurance SG, Andrade AC, Ribeiro JE, Capretz RL. 2006.

Rain forest fragmentation and the proliferation of successional trees. Ecology 87: 469-482.

Lawes MJ, Midgley JJ, Clarke PJ. 2013. Costs and benefits of relative bark thickness in relation to fire damage: a savanna/forest contrast. Journal of Ecology 101: 517-524.

Legendre P, Fortin MJ, Borcard D. 2015. Should the Mantel test be used in spatial analysis? Methods in Ecology and Evolution 6: 1239-1247.

Lewis SL, Lopez-Gonzalez G, Sonké B, Affum-Baffoe K, Baker TR, Ojo LO, Phillips OL, Reitsma JM, White L, Comiskey JA, et al. 2009. Increasing carbon storage in intact African tropical forests. Nature 457: 1003-1006.

Ludwig J a, Cornelius JM. 1987. Locating Discontinuities along Ecological Gradients. Ecology 68: $448-450$.

Maley J. 2002. A catastrophic destruction of African forests about 2,500 years ago still exerts a major influence on present vegetation formations. IDS Bulletin-Institute of Development Studies 33: 13-30. Marthews T, Riutta T, Oliveras Menor I, R U, Moore S, Metcalfe D, Malhi Y, Phillips O, Huasco H, Ruiz Jaén M, et al. 2014. Measuring Tropical Forest Carbon Allocation and Cycling: A RAINFOR-GEM Field Manual for Intensive Census Plots (v3.0).

McCleery R, Monadjem A, Baiser B, Fletcher R, Vickers K, Kruger L. 2018. Animal diversity declines with broad-scale homogenization of canopy cover in African savannas. Biological Conservation 226: 54-62.

Midgley JJ, Bond WJ. 2011. Pushing back in time: The role of fire in plant evolution. New

This article is protected by copyright. All rights reserved 
Phytologist 191: 5-7.

Midgley JJ, Kruger LM, Skelton R. 2011. How do fires kill plants? The hydraulic death hypothesis and Cape Proteaceae 'fire-resisters'. South African Journal of Botany 77: 381-386.

Mitchard ET a, Saatchi SS, Lewis SL, Feldpausch TR, Woodhouse IH, Sonké B, Rowland C,

Meir P. 2011. Measuring biomass changes due to woody encroachment and deforestation/degradation in a forest-savanna boundary region of central Africa using multi-temporal L-band radar backscatter. Remote Sensing of Environment 115: 2861-2873.

Moore S, Adu-Bredu S, Duah-Gyamfi A, Addo-Danso SD, Ibrahim F, Mbou AT, de Grandcourt A, Valentini R, Nicolini G, Djagbletey G, et al. 2017. Forest biomass, productivity and carbon cycling along a rainfall gradient in West Africa. Global Change Biology.

van Nes EH, Hirota M, Holmgren M, Scheffer M. 2014. Tipping points in tropical tree cover: linking theory to data. Global Change Biology 20: 1016-1021.

Odum EP. 1959. Fundamentals of ecology. W.B. Saunders company.

Oksanen J, Blanchet FG, Friendly M, Kindt R, Legendre P, McGlinn D, Minchin PR, O'Hara RB, Simpson GL, Solymos P, et al. 2019. vegan: Community Ecology Package (R Package).

Oliveira MA, Grillo AS, Tabarelli M. 2004. Forest edge in the Brazilian Atlantic forest: drastic changes in tree species assemblages. Oryx 38: 389-394.

Oliveras I, Malhi Y. 2016. Many shades of green: the dynamic tropical forest-savannah transition zones. Philosophical Transactions of the Royal Society B: Biological Sciences 371: 20150308.

Olsson EGA, Ouattara S. 2013. Opportunities and challenges to capturing the multiple potential benefits of REDD+ in a traditional transnational savanna-woodland region in West Africa. Ambio 42: 309-19.

Osborne CP. 2008. Atmosphere, ecology and evolution: What drove the Miocene expansion of C4 grasslands? Journal of Ecology 96: 35-45.

Parr CL, Gray EF, Bond WJ. 2012. Cascading biodiversity and functional consequences of a global change-induced biome switch. Diversity \& Distributions 18: 493-503.

Parr CL, Lehmann CER, Bond WJ, Hoffmann W a., Andersen AN. 2014. Tropical grassy biomes: Misunderstood, neglected, and under threat. Trends in Ecology and Evolution 29: 205-213. Pausas JG, Bond WJ. 2020. Alternative biome states in terrestrial ecosystems. Trends in Plant 
Science.

Peres CA, Tabarelli M, Aguiar A V, A LCGIR. 2010. Effects of Pioneer Tree Species Hyperabundance on Forest Fragments in Northeastern Brazil. Conservation Biology 24: 1654-1663.

Poorter L, Bongers F. 2006. Leaf Traits Are Good Predictors of Plant Performance across 53 Rain Forest Species. Ecology 87: 1733-1743.

R Development Core Team. 2018. R: A language and environment for statistical computing.

Ratnam J, Bond WJ, Fensham RJ, Hoffmann WA, Archibald S, Lehmann CER, Anderson MT, Higgins SI, Sankaran M. 2011. When is a 'forest' a savanna, and why does it matter? Global Ecology and Biogeography 20: 653-660.

Ratter JA, Bridgewater S, Atkinson R, Ribeiro JF. 1996. Analysis of the floristic composition of the Brazilian cerrado vegetation II: Comparison of the woody vegetation of 98 areas. Edinburgh Journal of Botany 53: 153-180.

Ratter JA, Dargie TCD. 1992. An analysis of the floristic composition of 26 cerrado areas in brazil. Edinburgh Journal of Botany 49: 235-250.

Reis SM, de Oliveira EA, Elias F, Gomes L, Morandi PS, Marimon BS, Marimon Junior BH, das Neves EC, de Oliveira B, Lenza E. 2017. Resistance to fire and the resilience of the woody vegetation of the "Cerradão" in the "Cerrado"-Amazon transition zone. Revista Brasileira de Botanica 40: 193-201.

Rosan TM, Aragão LEOC, Oliveras I, Phillips OL, Malhi Y, Gloor E, Wagner FH. 2019. Extensive 21st-Century Woody Encroachment in South America's Savanna. Geophysical Research Letters 46: 6594-6603.

Scheiter S, Higgins SI. 2009. Impacts of climate change on the vegetation of Africa: An adaptive dynamic vegetation modelling approach. Global Change Biology 15: 2224-2246.

Scheiter S, Schulte J, Pfeiffer M, Martens C, Erasmus BFN, Twine WC. 2019. How Does Climate Change Influence the Economic Value of Ecosystem Services in Savanna Rangelands? is. Ecological Economics 157: 342-356.

Scholes RJ, Archer SR. 1997. Tree-Grass Interactions in Savannas. Annual Review of Ecology and Systematics 28: 517-544.

Seddon AWR, Macias-Fauria M, Long PR, Benz D, Willis KJ. 2016. Sensitivity of global 
terrestrial ecosystems to climate variability. Nature 531: 229-232.

Sharp D. 2015. Your Chi-Square Test is Statistically Significant: Now What? Practical Assessment, Research and Evaluation 20: 1-10.

Silvério D V., Brando PM, Balch JK, Putz FE, Nepstad DC, Oliveira-Santos C, Bustamante

MMC. 2013. Testing the Amazon savannization hypothesis: Fire effects on invasion of a neotropical forest by native cerrado and exotic pasture grasses. Philosophical Transactions of the Royal Society

B: Biological Sciences 368: 12-14.

Smith MD, Van Wilgen BW, Burns CE, Govender N, Potgieter ALF, Andelman S, Biggs HC,

Botha J, Trollope WSW. 2013. Long-term effects of fire frequency and season on herbaceous vegetation in savannas of the Kruger National Park, South Africa. Journal of Plant Ecology 6: 71-83.

Sokal RR, Rohlf FJ. 1995. Biometry - The Principles and Practice of Statistics in Biological Research. New York: W.H. Freeman and Co.

Staver AC. 2017. Prediction and scale in savanna ecosystems. New Phytologist.

Staver AC, Archibald S, Levin S a. 2011. The Global Extent and Determinants of Savanna and Forest as Alternative Biome States. Science 334: 230-232.

Staver AC, Brando PM, Barlow J, Morton DC, Paine CET, Malhi Y, Araujo Murakami A, del Aguila Pasquel J. 2019. Thinner bark increases sensitivity of wetter Amazonian tropical forests to fire. Ecology Letters.

Stevens N, Erasmus BFN, Archibald S, Bond WJ. 2016. Woody encroachment over 70 years in South African savannahs: overgrazing, global change or extinction aftershock? Philosophical Transactions of the Royal Society B: Biological Sciences 371: 20150437.

Stevens N, Lehmann CER, Murphy BP, Durigan G. 2017. Savanna woody encroachment is widespread across three continents. Global Change Biology 23: 235-244.

Tabarelli M, Lopes A V, Peres CA. 2008. Edge-effects Drive Tropical Forest Fragments Towards an Early-Successional System. Biotropica 40: 657-661.

Tabarelli M, Mantovani W, Peres CA. 1999. Effects of habitat fragmentation on plant guild structure in the montane Atlantic forest of southeastern Brazil. Biological Conservation 91: 119-127.

Tutin CE, Abernethy K, Musgrave R, Jeffery KJ, Moussavou, G., Mihindou V, Malhi Y, Lehmann D, Ndong JE, Makaga L, Bush ER. 2019. Lopé Weather Dataset. DataSTORRE. 
Veldman JW. 2016. Clarifying the confusion: old-growth savannahs and tropical ecosystem degradation. Philosophical Transactions of the Royal Society B: Biological Sciences 371: 20150306. Veldman JW, Overbeck GE, Negreiros D, Mahy G, Le Stradic S, Fernandes GW, Durigan G, Buisson E, Putz FE, Bond WJ. 2015. Where Tree Planting and Forest Expansion are Bad for Biodiversity and Ecosystem Services. BioScience 65: 1011-1018.

Veldman JW, Putz FE. 2011. Grass-dominated vegetation, not species-diverse natural savanna, replaces degraded tropical forests on the southern edge of the Amazon Basin. Biological Conservation 144: 1419-1429.

Verhegghen A, Eva H, Ceccherini G, Achard F, Gond V, Gourlet-Fleury S, Cerutti PO. 2016.

The potential of sentinel satellites for burnt area mapping and monitoring in the Congo Basin forests. Remote Sensing 8: 1-22.

Walker S, Wilson JB, Steel JB, Rapson GL, Smith B, King WMG, Cottam YH. 2003. Properties of ecotones: Evidence from five ecotones objectively determined from a coastal vegetation gradient. Journal of Vegetation Science 14: 579-590.

van de Weghe JP. 2011. Les Parcs Nationaux du Gabon: Lopé, Waka et Monts Birougou. Libreville, Gabon: ANPN and WCS Gabon.

White F. 1983. The vegetation of Africa: A descriptive memoir to accompany the Vegetation Map of Africa.

White LJT. 1995. Project ECOFAC: Vegetation Study - Final Report, République du Gabon. White LTJ. 2001. Forest-savanna dynamics and the origins of the Marantacea forest in central Gabon. In: Weber B, White L, Vedder A, Naugthon-Treves L, eds. African Rain Forest Ecology and Conservation. New Haven, Conneticut: Yale University Press, 165-182.

White LTJ, Abernethy KA. 1997. A guide to the vegetation of Lope Reserve Gabon. Libreville, Gabon: Multipress-Gabon.

Willis KJ, Bennett KD, Burrough SL, Macias-Fauria M, Tovar C. 2013. Determining the response of African biota to climate change : using the past to model the future Determining the response of African biota to climate change : using the past to model the future. Philosophical transactions of the royal society: 1-9.

Wright IJ, Reich PB, Westoby M, Ackerly DD, Baruch Z, Bongers F, Cavender-Bares J,

This article is protected by copyright. All rights reserved 
Chapin T, Cornellssen JHC, Diemer M, et al. 2004. The worldwide leaf economics spectrum. Nature 428: 821-827.

This article is protected by copyright. All rights reserved 